\title{
Dacryoliths causing intermittent epiphora associated with a patent lacrimal system
}

\section{Dacriolitíase causando epífora intermitente associada a um sistema lacrimal de patente}

\author{
Yerena Muiños Díaz $^{1}$, Alicia Galindo-Ferreiro ${ }^{2,3}$, Patricia M. Akaishi ${ }^{2,4}$
}

\begin{abstract}
We present two patients with dacryoliths and patent lacrimal drainage with intermittent tearing and without infection. Dacryoliths can be present in the lacrimal sac or lacrimal duct without acute or chronic inflammation. In these cases, we believe dacryolith formation was a causative factor of intermittent epiphora even with a patent drainage system, and we propose that dacryoliths and even fungal colonization formation may be the first event before dacryocystitis and should be considered as a cause of epiphora.
\end{abstract}

Keywords: Lacrimal apparatus diseases; Dacryocystitis

\section{RESUMO}

Apresentamos dois pacientes com dacriolitíase e drenagem lacrimal patente com lacrimejamento intermitente, sem infecção. Os dacriolitos podem estar presentes no saco lacrimal ou duto lacrimal, sem inflamação aguda ou crônica. Neste caso nós acreditamos que a dacriolitíase foi um fator causador da epífora intermitente mesmo com sistema de drenagem patente e propomos que dacriolitíase e até mesmo a colonização fúngica pode ser o primeiro evento antes dacriocistite, e deve ser adicionada como uma das causas de epífora.

Descritores: Doenças do aparelho lacrimal; Dacriocistite

\section{INTRODUCTION}

Dacryoliths are concretions found within the nasolacrimal system that usually comprise lipids, epithelial cells, and other debris. A dacryolith (lacrimal calculus or ophthalmolith) can arise de novo or by the precipitation of calcium and phosphate salts on foreign material(1). Signs and symptoms of dacryoliths include intermittent epiphora without inflammation or recurrent dacryocystitis ${ }^{(1)}$. Dacryoliths can cause inflammation and acute or chronic dacryocystitis, with intermittent or persistent symptoms ${ }^{(2)}$. We present two case reports of dacryoliths with fungal involvement and a patent nasolacrimal duct. These cases highlight dacryoliths as a cause of intermittent tearing despite a patent nasolacrimal system. We propose that dacryolith and even fungal colonization formation may be the first event before dacryocystitis.

\section{CASE REPORTS}

\section{CASE 1}

A 34-year-old woman presented with grade III intermittent epiphora in the right eye with onset 8 months before presentation. The patient had no previous history of infection. The ophthalmic examination was unremarkable, and the lacrimal drainage system was patent with no mucus or discharge. A dye disappearance test showed normal passage, and irrigation into the nose without reflux indicated a patent nasolacrimal system. As the intermittent epiphora continued, causing a high degree of anxiety in the patient, we suspected incomplete Hasner membrane formation and performed an endonasal dacryocystorhinostomy. Although we did not suspect dacryoliths as a cause of intermittent epiphora in this case, numerous yellowish dacryoliths were found, and samples were sent for histopathologic examination. The gross histopathologic examination revealed multiple yellowish granules, ranging in length from 0.5 to $>2 \mathrm{~mm}$. Microscopic evaluation using hematoxylin and eosin (H\&E) stain indicated a fibro-osseous tissue with mixed inflammatory infiltrate and fungal structures. Periodic acid-Schiff staining with diastase revealed fungal conidia and hyphae (Figure 1 left), and the laboratory analysis was positive for Candida albicans. At the 2-year follow-up visit, the epiphora was completely resolved with no treatment.

\section{Case 2}

A 48-year-old man presented with grade III intermittent epiphora for 3 months in the right eye. There was no history of ocular infections or discharge from the eye. His ocular examination was unremarkable, and the puncta, canaliculus, lacrimal sac, and anterior segment were normal. A dye disappearance test showed normal passage, and irrigation was patent into the nose without reflux. However, 10 min after the irrigation, there was a spontaneous passage of cream-colored hard material into the patient's throat. The gross histopathologic examination indicated two fragments. Microscopic evaluation using H\&E and Grocott's methenamine silver staining revealed fungal conidia and hyphae (Figure 1 right), and the laboratory analysis was positive for $C$. albicans. The epiphora resolved immediately without treatment, and there had been no recurrence at the 1-year follow-up visit.

\section{DISCUSSION}

Dacryoliths are observed in up to $32 \%$ of patients with acute dacryocystitis who undergo dacryocystorhinostomy ${ }^{(3)}$. Dhillon et al. ${ }^{(4)}$
Funding: No specific financial support was available for this study.

Disclosure of potential conflicts of interest: None of the authors have any potential conflict of interest to disclose.

Corresponding author: Yerena Muiños Diaz. Ophthalmology Consultation. Hospital Nuestra Señora de Fátima. Via Norte 48 - Vigo - Pontevedra 36206 Spain - Email: oftalmologo@hotmail.es 
reported that of 327 patients who underwent dacryocystorhinostomy, $7.4 \%$ had dacryoliths, Repp et al. ${ }^{(5)}$ reported a $6.7 \%$ incidence of dacryoliths, and Yazici et al. ${ }^{(6)}$ reported an overall frequency of dacryoliths of $7.4 \%$ in 163 cases, all with an obstructed nasolacrimal duct. Although the underlying etiology of dacryoliths remains unknown, various theories have been proposed ${ }^{(4)}$. Most patients with chronic tearing have drainage insufficiency caused by abnormalities anywhere along the outflow pathway including punctal disorders, canalicular or lacrimal pump deficiencies, lacrimal sac or duct abnormalities, or intranasal pathology. Lacrimal sac diverticula; alterations in the channel wall, flow, or fluid; chronic obstruction and inflammation of the sac; and Hasner valve abnormalities result in dehydration and denaturation of proteins in the tear ducts that could contribute to dacryolith formation ${ }^{(2,7)}$

Another theory is that chronic inflammation coupled with the factors described above can cause lacrimal wall changes, membrane formation, and accumulation of debris with alteration of microbial flora. These changes could precipitate dacryolith formation and microbial and fungal colonization as seen in both cases presented here ${ }^{(7)}$.

Membrane formation that allows movement of the dacryolith or fragmentation of the dacryolith could improve fluid flow through the lacrimal sac and duct, which may explain the intermittent symptoms in some patients ${ }^{(7)}$.

Cases of fungal colonization of dacryoliths have spurred some to question whether the dacryoliths are a result of chronic fungal dacryocystitis or whether the fungal growth occurs secondary to the alteration of the flow and dacryolith formation ${ }^{(3)}$.

Most cases reports of dacryoliths in the literature involve acute or chronic dacryocystitis, some with intermittent epiphora, reflux during irrigation, and rarely, slight passage into the nasopharynx. To date, only Rosen and Rose ${ }^{(2)}$ have reported two cases of dacryoliths with a patent lacrimal drainage system, but both patients had dacryocystitis. Rosen and Rose $^{(2)}$ stated that the possible nidi were fungus, yeast, and eyelashes. Table 1 lists the clinical symptoms and clinical examination findings of dacryocystitis cases reported in the literature.

Our cases show that dacryoliths, or putty-like casts, originating in the nasolacrimal system may cause intermittent epiphora and that the casts can be passed relatively readily or spontaneously. As previously proposed by Hawes ${ }^{(3)}$, the intermittent symptoms in our patients were likely due to positional changes of the dacryoliths in the lacrimal system.

In our cases, the patients had no history of infection, sac distention, lacrimal reflux, or mucous secretions. Dacryolith and even fungal colonization formation could be the first events before dacryocystitis. The presence of inflammatory debris in the biopsy of our first case suggests at least a low level of dacryocystitis.

In many patients with complaints of tearing, a comprehensive evaluation of factors affecting the tear drainage system is neglected. However, ultrasonography, radiography, and dacryocystography have demonstrated dacryoliths in the lacrimal sac and nasolacrimal duct ${ }^{(1)}$.
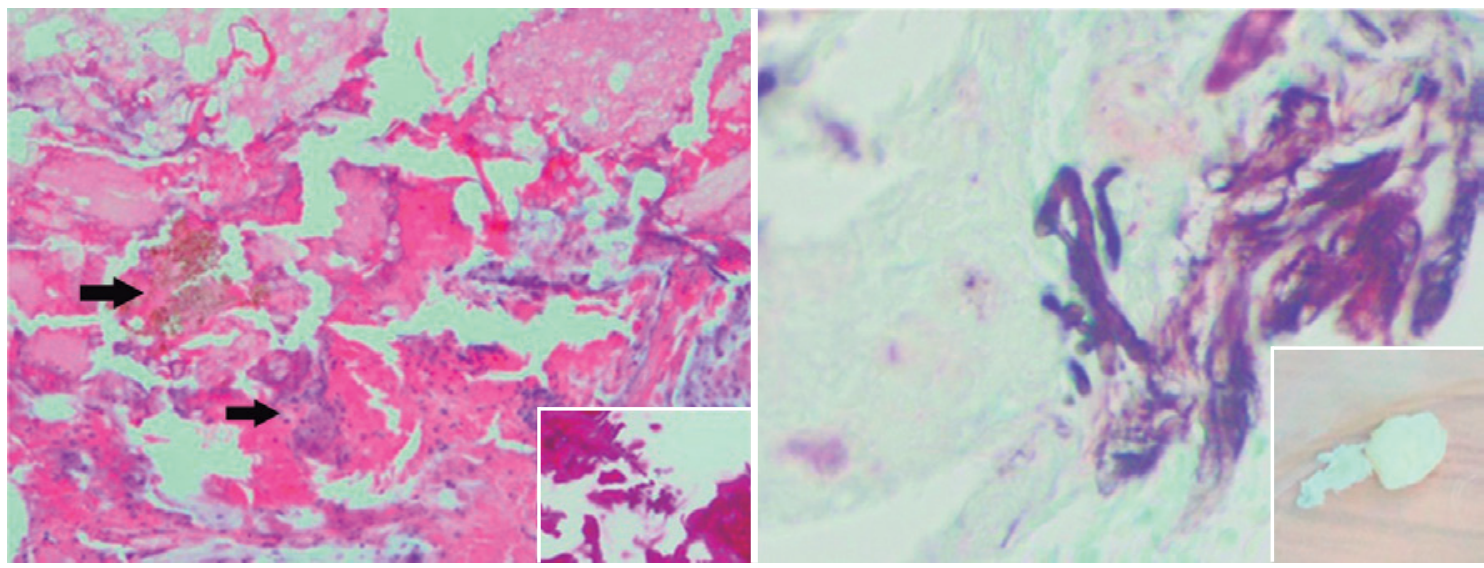

Figure 1. Left, case 1: Hematoxylin and eosin staining revealed fibro-osseous tissue with mixed inflammatory infiltrate (thin arrow) and fungal structures (thick arrow). Periodic acid-Schiff staining revealed Candida hyphae Magnification, $\times 40$. Right, case 2: Grocott's methenamine silver staining revealed fungal conidia and Candida-type hyphae with whitish.

Table 1. Dacryocystitis cases in the literature: clinical examination and findings

\begin{tabular}{|c|c|c|c|c|c|c|c|}
\hline Study & № of cases & Age (years) & Irrigation test results & Symptoms & Duration of symptoms (years) & Dacryoliths & Surgery \\
\hline \multirow[t]{2}{*}{ Aydin et al..$^{(1)}$} & 2 & 57 & Not patent & Dacryocystitis & 5 & No & Yes \\
\hline & & 44 & Not patent & Tearing & 1 & No & Yes \\
\hline \multirow[t]{2}{*}{ Rosen and Rose. ${ }^{(2)}$} & 2 & 33 & Patent & Dacryocystitis & 8 & Aspergillus & No \\
\hline & & 35 & Patent & Dacryocystitis & 13 & No & No \\
\hline Dhillon et al. ${ }^{(4)}$ & 1 & 63 & Not patent & Dacryocystitis & Long-term & No & Yes \\
\hline \multirow[t]{5}{*}{ \|liadelis, et al. ${ }^{(7)}$} & 5 & 42 & Not patent & Dacryocystitis & 3 & No & Yes \\
\hline & & 22 & Not patent & Dacryocystitis & 2 & No & Yes \\
\hline & & 36 & Not patent & Dacryocystitis & 3 & No & Yes \\
\hline & & 28 & Not patent & Dacryocystitis & 3 & No & Yes \\
\hline & & 53 & Not patent & Dacryocystitis & 4 & No & Yes \\
\hline
\end{tabular}


In conclusion, dacryoliths in the lacrimal sac should be considered a cause of intermittent tearing and should be evaluated using the irrigation test.

\section{REFERENCES}

1. Aydin U, Hastar E, Yildirim D. Dacryolith: two case reports. Dentomaxillofac Radiol. 2007; 36(4):237-9.

2. Rosen WJ, Rose GE. Intranasal passage of dacryoliths Br J Ophthalmol. 2000;84(7):799-800.
3. Hawes MJ. The dacryolithiasis syndrome. Ophthal Plast Reconstr Surg. 1988;4(2): $87-90$

4. Dhillon N, Kreis AJ, Madge SN. Dacryolith-induced acute dacryocystitis: a reversible cause of nasolacrimal duct obstruction. Orbit. 2014;33(3):199-201.

5. Repp DJ, Burkat CN, Lucarelli MJ. Lacrimal excretory system concretions: canalicular and lacrimal sac. Ophthalmology. 2009;116(11):2230-5.

6. Yazici B, Hammad AM, Meyer DR. Lacrimal sac dacryoliths: predictive factors and clinical characteristics. Ophthalmology. 2001;108(7):1308-12.

7. Iliadelis E, Karabatakis V, Sofoniou M. Dacryoliths in chronic dacryocystitis and their composition (spectrophotometric analysis). Eur J Ophthalmol. 1999;9(4):266-8.

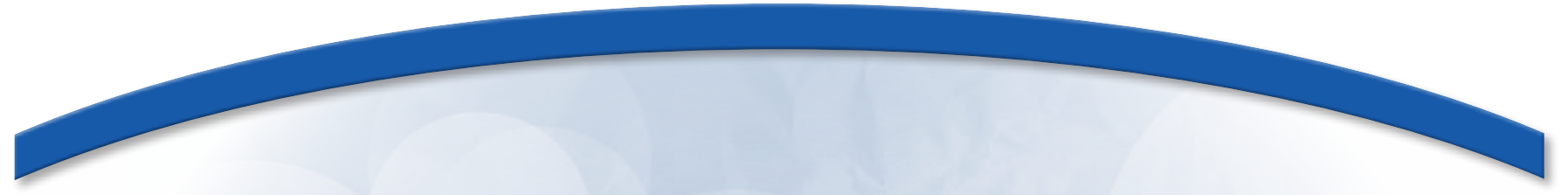

\title{
IX Congresso Brasileiro de Catarata e Cirurgia Refrativa
}

\section{Congresso Brasileiro de Administração em Oftalmologia}

\author{
II Congresso Brasileiro de \\ Enfermagem em Oftalmologia
}

\section{1 de maio a 3 de junho de 2017}

\section{Rafain Palace Hotel}

Foz do Iguaçu - PR

\section{Informações:}

Tel.: (45) 3025-2121

E-mail: alvo@alvoeventos.com.br

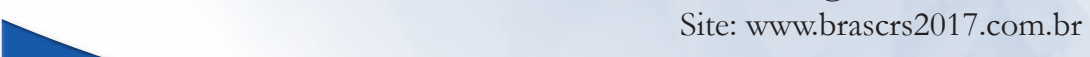

